\title{
A STUDY ON THE FLATUS POTENTIAL OF DIETARY FIBRE FROM SOME LEGUMES
}

\section{G. RAVINDRAN}

Department of Food Science and Technology, Faculty of Agriculture, University of Peradeniya, Peradeniya, Sri Lanka .

(Date of receipt

(Date of acceptance
19. January 1990).

07 August 1990)

\begin{abstract}
The in-vitro flatus causing tendancy of soluble and insoluble fibre fractions from four legumes, namely, blackgram, greengram, soybean and wingedbean by Clostridium perfringens was investigated. The gas production from the soluble fibre fraction of blackgram, soybean and wingedbean was relatively high and was similar to that from raffinose; whereas gas production from the soluble fibre fraction of greengram was low. The insoluble fibre fractions of all four legumes were found to have littie or no flatus activity. Gas chromatographic analysis of the flates gases revealed $\mathrm{H}_{2}$ and $\mathrm{CO}_{2}$ to be the predominent components of gas production.
\end{abstract}

\section{Introduction}

The legumes are generally implicated in causing flatulence, though the extent of their involvement is not clearly known. Many investigators ${ }^{2}, 3,1.3$ hypothesize that some legume carbohydrates, especially the galactosecontaining oligosaccharides, escape digestion and absorption in the small intestine and are later subjected to microbial fermentation in the large intestine, resulting in the production of gases. ${ }^{1,9}$ This is supported by the fact that the human alimentary canal does not produce the enzyme galactosidase ${ }^{6}$ which is essential for the hydrolysis and absorption of these oligosaccharides. However, the microflora in the human colon can produce this enzyme and can therefore be expected to ferment this carbohydrate.

Though flatulence is generally attributed to short-chain oligosaccharides, there is some evidence that other carbohydrates may also be involved. Rackis $e t a l^{10}{ }^{10}$ reported that the flatus principle of soybean is in the water soluble, low molecular weight carbohydrate fraction and not in the hulls, fat, protein or the water insoluble residue. However Murphy et al. ${ }^{8}$ have reported that the water insoluble polysaccharides may also be responsible. Flemings studied the flatus potential of seven legumes and reported oligosaccharides, glucose and pentosans and not the starch or lignin to be responsible for hydrogen production. El Faki et al. ${ }^{4}$, in their flatulence studies in vivo and in vitro on chick pea, cowpea and horsegram, found not only oligosaccharides, but also starch and hemicellulose to contribute substancially to the flatus, condition. 
In the present study, the flatulence potential of soluble and insoluble dietary fibre fractions of four legumes, viz black gram(BG), greengram(GG), soybean (soy) and winged bean (WB), compared to raffinose and glucose, were established by incubation with anaerobic Clostridium perfringens. The amount of gas produced was taken as the parameter indicative of the possible flatus producing ability.

\section{Materials and Methods}

\subsection{Sample Preparation}

Mature seeds of four legumes viz. blackgram (variety MI 1), greengram (variety MI 5), soybean (variety PB 1) and winged bean (variety TPT-2) were obtained from the Dry Zone Agriculture Research Station, MahaIluppallama. They were gound in a Wiley laboratory mill to pass through a 60-mesh sieve and defatted with hexane for $8 \mathrm{~h}$.

\subsection{Preparation of Soluble and Insoluble Fibre Fractions}

The enzymatic method of Hellendoorn, ${ }^{7}$ as modified by Schweizer and Wursch $^{12}$ was used to isolate the soluble and insoluble fibre from the defatted flours. This approach involved stepwise removal of proteins with pepsin and pancreatin, and starch with glucomylase. The resudue forms the insoluble fibre (ENZ-I). The precipitation from the supernatant with 4 volumes of ethanol gives soluble fibre $(\mathrm{ENZ}-\mathrm{S})$.

\subsection{In Vitro Gas Production}

In vitro gas production on soluble and insoluble fibre fractions of the legumes, with glucose and raffinose as control sugars, was carried out anaerobically using Clostridium perfringens of intestinal origin and a thioglycollate medium, according to the method of Richards et al. ${ }^{11}$, as modified by El Faki et $a .^{4}$

The fibre fractions and sugars were incorporated into the media at $1 \%$ level and autoclaved at $15 \mathrm{psig}, 120^{\circ} \mathrm{C}$ for $15 \mathrm{~min}$. Test tubes, each containing $14 \mathrm{ml}$ of media were incubated overnight at $37 \mathrm{C}$ to check for contamination. The media was then mixed with $1 \mathrm{ml}$ inoculum from a $24 \mathrm{~h}$ old culture of Clostridium perfringens and the mixture then drawn into $30 \mathrm{ml}$ glass syringes. The outlet of the syringe was plugged with sterile serum rubber stoppers and the mixture incubated at $37^{\circ} \mathrm{C}$ for $24 \mathrm{~h}$. The gas produced was directly measured from the movement of the syringe barrel. Two controls were run, one without organism and the other without carbohydrates. 


\subsection{Determination of Gas Composition}

The gas collected above was analysed for its constituent gases by the use of a Fisher Hamilton Gas Partitioner connected to a Fisher Scientific Series 260 recorder. A two column standard system was used. The first column was a $6 \mathrm{ft} \times 1 / 4$ in ID glass packed with $30 \% \mathrm{DC}-2-$ ethyl-hexylsebacate ōn 60-80 mesh column pak and the second column was a $6 \frac{12}{2} \mathrm{ft} \times 3 / 16$ in $\mathrm{ID}$ glass packed with 40-60 mesh molecular sieve.

The $\mathrm{CO}_{2}$ concentration in $0.5 \mathrm{ml}$ of each gas sample was determined using both columns 1 and 2 with helium as the carrier gas at $40 \mathrm{ml} / \mathrm{min}$ and attenuation $8 \mathrm{x}$. The hydrogen content in $0.5 \mathrm{ml}$ of gas mixture was analysed using column 2 only with argon as the carrier gas at a flow of $30 \mathrm{ml} / \mathrm{min}$ at $16 \mathrm{x}$ attenuation. Concentration of $\mathrm{CO}_{2}$ and $\mathrm{H}_{2}$ in the gas mixture was calculated from peak height measurements, relative to peak heights for pure $\mathrm{H}_{2}$ and $\mathrm{CO}_{2}$.

\subsection{Replication}

The study was repeated thrice so as to obtain more reliable data.

\section{Results and Discussion}

The volume and percent composition of the gas produced are presented in Tables 1 and 2, respectively. Bacteria incubated on glucose produced the greatest volume $(20 \mathrm{cc}$ ) of gas within 4 hours of incubation. In cultures incubated on raffinose, gas production was slower, reaching only $10 \mathrm{cc}$ by $24 \mathrm{~h}$. The insoluble fibre fraction of all four legumes produced little or no gas during the $24 \mathrm{~h}$ incubation period. In contrast, the soluble fibre fractions of $\mathrm{BG}$, soy and $\mathrm{WB}$ produced a net volume of 8,7 and 6 cc respectively, by $24 \mathrm{~h}$. However, gas production from these fractions was low. $(3 \mathrm{cc})$ during the first $8 \mathrm{~h}$, a trend similar to that observed for raffinose. The soluble fibre fraction of green gram behaved in a manner different to other three legumes ; the gas production was only 3 cc even after $24 \mathrm{~h}$ of incubation.

Carbon dioxide and Hydrogen were the two predominant constituents of the gas produced, confirming that a typical flatus producing system was being tested. ${ }^{10}$ The ratio of $\mathrm{H}_{2} \therefore \mathrm{CO}_{2}$ was $<1$ for raffinose $(0.96)$ and glucose $(0.86)$, while this ratio was $>1$ for soluble fibres of BG, Soy and WB. The percent composition measurements (Table 2) consistently yielded values somewhat greater than $100 \%(104-107 \%)$. The $\mathrm{CO}_{2}$ and $\mathrm{H}_{2}$ were measured independently on two different columns and utilizing two different gas mixture to calibrate the columns. The high values probably resulted 
Table 1: Gas Production in vitro of Soluble Incoluble Fibre Fractions of Blackgram (B G ), Greengram (G G.), Soybean (Soy) and Winged Bean (W.B ).

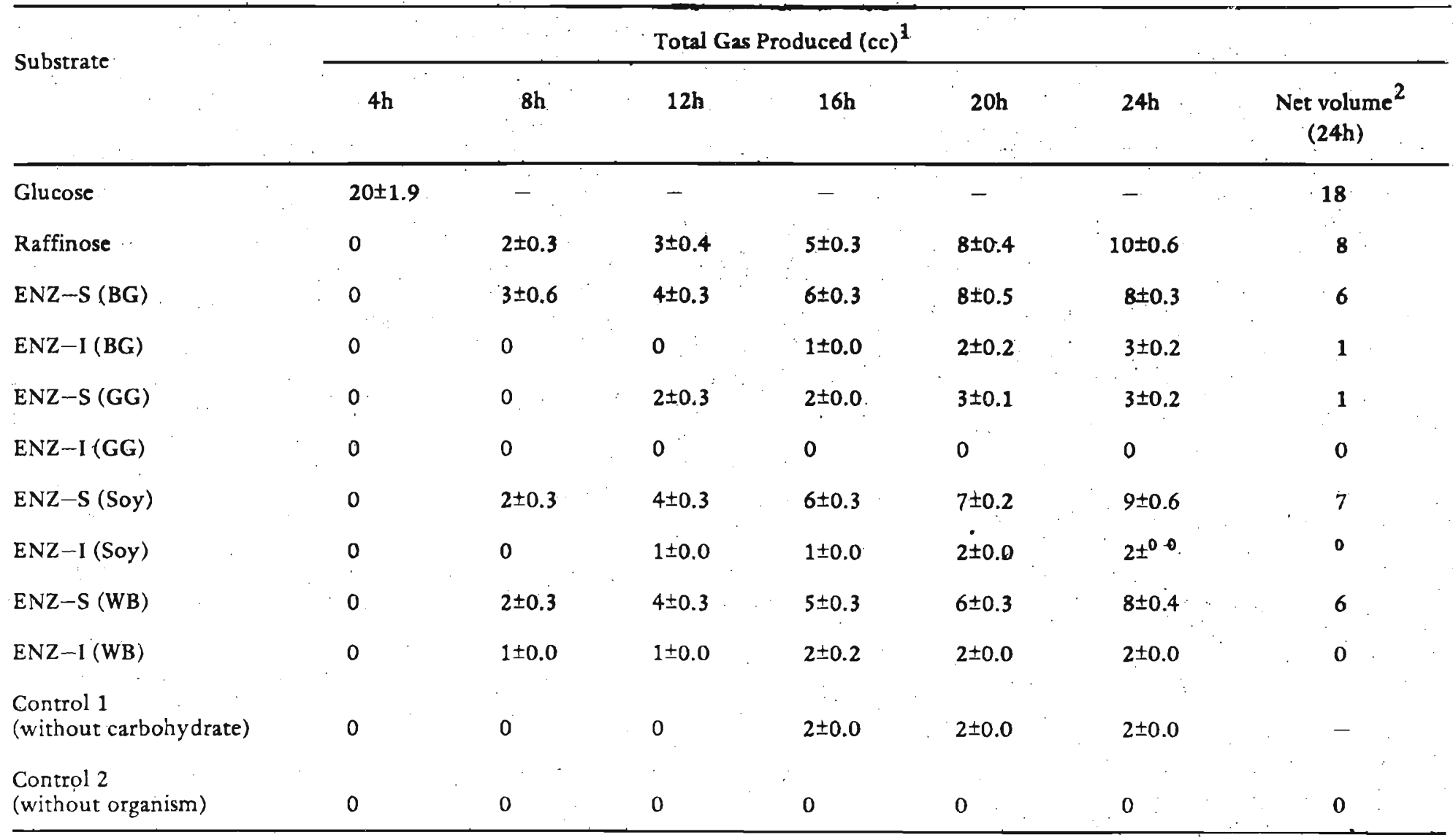

${ }_{1}$ Each value represents mean \pm standard deviation 
Table 2. Composition of the Gas produced by the Soluble and Insoluble Fibre Fractions of Black Gram (BG), Green Gram (GB), Soybean (Soy) and Winged Bean (WB).

\begin{tabular}{lll}
\hline Substrate & \multicolumn{2}{c}{$\begin{array}{c}\text { Gas Composition }(\%)^{1} \\
\mathrm{CO}_{2}\end{array}$} \\
\hline Glucose & $57 \pm 1.5$ & $49 \pm 3.7$ \\
Raffinose & $53 \pm 6.0$ & $51 \pm 4.1$ \\
ENZ $\rightarrow$ S (BG) & $43 \pm 4.0$ & $52 \pm 4.0$ \\
ENZ - I (BG) & - & - \\
ENZ - S (GG) & - & - \\
ENZ - I (GG) & - & - \\
ENZ - S (Soy) & $48 \pm 3.0$ & $59 \pm 3.6$ \\
ENZ - I (Soy) & - & - \\
ENZ - S (WB) & $50 \pm 4.6$ & $57 \pm 4.8$ \\
ENZ - I (WB) & - & - \\
\hline
\end{tabular}

${ }^{1}$ Mean \pm Standard deviation.

from an error in one of or both the systems, most likely from an error in the stated concentrations $\left(\mathrm{CO}_{2}\right.$ or $\left.\mathrm{H}_{2}\right)$ of calibration gases.

The results show that the insoluble fibres have little or no flatus activity, probably because they are not hydratable. These findings are consistent with those of Rackis et al. ${ }^{10}$. who reported that the water insoluble residue of soy has no flatus activity.

The soluble fibres of BG, Soy and WB were found to have relatively high flatus activity. Although the production of latus gas from these soluble fibres was lower than that from glucose, gas formation was comparable to that of raffinose, a well established causative factor of flatulence. ${ }^{2,3}$ The isolation procedure employed in the present study was specifically designed to yield sugar-free fibre preparations. Thus the gas production did not arise from the presence of raffinose or stachyose in ENZ-S of BG, Soy or WB. The soluble fibre of GG showed little or no flatus activity; confirming the results of Fleming. 6 The flatus potential of WB has not been previously reported. The present results indicate that the flatus causing ability of the WB soluble fibre is similar to those of soy and BG.

The results of the present study showed that soluble fibre fractions of some legumes play a definite role in flatus activity. However, further studies will be required to delineate the exact nature of this contribution to flatus production. The ultimate test will be to feed purified soluble fibre fractions to human subjects and measure the time-course production, as described by Wagner et al. ${ }^{14}$ 


\section{References}

1. ANDERSON, R. L., RACKIS, J. J. \& TAllent, W. H. (1979) In "Soy Protein and Human Nutrition", p. 209, Ed. H. L. WILCKE, D. T. HOPKINS and D. H. WAGGLE, Academic Press, New York.

2. Calloway, D. H., COlasito, D. J. \& MATHIWS, R. D. (1966) Nature. 212 : 1238.

3. CAlloway, D. H. \& MURPHY, E. L. (1968) Amm. N. Y. Acad. Sci $150: 82$.

4. El FAKI, H. A., BHAVANISHANGAR, T. N., THARANATHAN, R. N. \& DESIKACHAR, H. S. R. (1983) Nutr. Rep. Intl. $27: 921$.

5. FLEMING, S. E. (1981) J. liood Sci. $46: 794$

6. GITZELMAN, R. \& AURICCHIO, S. (1965) pediatrics $36: 231$.

7. HELLENDOORN, E. W. (1975) J. Sci. Food Agric. $26: 1461$.

8. MURPHY, E. L., HORSLEY, H. \& BURR, H. K. (1972) J. Agr. Jood Cbim. $20: 813$.

9. RACKIS, J. J. (1975) In "Physiological Effects of Food Carbobydrates". p. 207. [.d. A. JEANES \& J. HODGE, Amer. Chem. Soc., Washington, D. C.

10. RACKIS, J. J., HONIG, D. H., SESSA, D. J. \& STAGgERDA, F. R. (1970) J. Agr. lood Chem., 18 : 977.

11. RICHARDS, E. A., STAGGERDO, F. R. \& MURATA, A. (1968) Gastroenterology 55 : 502.

12. SCHWEIZER, T. F. \& WURSCH, P. (1981) The Analysis of Dietary Fiber in Food, p. 203. Ed. W. P. T. JAMES \& O. THEANDER, MARCEL DEKKER, Inc., New York.

13. STAGGERDA, F. R. (1968) Ann. N. Y. Acad. Sci. $150: 57$.

14. WAGNER, J. R., BECKER, R., GUMBMANN, H. R. \& OLSON, A. C. (1976) I. Nut? 106 : 466. 